\title{
PENGUJIAN AKTIVITAS INHIBITOR LIPASE EKSTRAK ETANOL DAN HASIL FRAKSIONASI DARI KEDELAI DETAM 1 DAN DAUN JATI BELANDA
}

\author{
Meilinah Hidayat ${ }^{1 *}$, Sylvia Soeng ${ }^{2}$, Sijani Prahastuti ${ }^{3}$ \\ ${ }^{1}$ Bagian Gizi Fakultas Kedokteran Universitas Kristen Maranatha Bandung, \\ ${ }^{2}$ Bagian Biologi Fakultas Kedokteran Universitas Kristen Maranatha Bandung, \\ ${ }^{3}$ Bagian Biokimia Fakultas Kedokteran Universitas Kristen Maranatha Bandung. \\ Jalan Prof. Drg. Suria Sumantri MPH no. 65 Bandung 40164 \\ *Alamat korespondensi: meilinah.hidayat@ maranatha.edu
}

\begin{abstract}
Abstrak: Salah satu pilihan pengelolaan obesitas adalah memperlambat absorbsi asam lemak dengan cara menginhibisi enzim lipase dalam saluran pencernaan. Inhibitor lipase pankreas dilaporkan telah berhasil dalam pengelolaan terapi obesitas. Senyawa aktif dalam Jati Belanda dan kedelai dapat berfungsi sebagai inhibitor lipase. Tujuan penelitian ini adalah mengetahui aktifitas lipase dari ekstrak etanol kedelai Detam 1 (EEKD), daun Jati Belanda (EEJB), kombinasi serta hasil fraksionasinya menggunakan metode standar dan modifikasi. Uji aktifitas lipase terhadap EEKD, EEJB, kombinasinya serta fraksi etil asetat, air dan $n$-heksana menggunakan kit Lipase Liquicolor (HUMAN ${ }^{\circledR}$ ) dengan prinsip kolorimetri, menggunakan spektrofotometer $580 \mathrm{~nm}$. Metode modifikasi menggunakan 96 well plate, microplate reader $630 \mathrm{~nm}$. Penelitian ini menyimpulkan bahwa aktifitas inhibitor lipase tertinggi didapatkan pada sampel kombinasi EEKD:EEJB perbandingan 1:2, baik menggunakan metode standar maupun metode modifikasi; fraksi yang mengandung aktifitas inhibitor lipase paling tinggi adalah fraksi air kedelai Detam 1 (KD-1) dan air Jati Belanda (JB) pada 100 ppm, serta aktifitas lipase dalam fraksi air JB lebih tinggi dari fraksi air KD-1.
\end{abstract}

\section{Kata kunci: aktivitas lipase, kedelai Detam 1, Jati Belanda}

ABSTRACT: Pancreatic lipase inhibitors are reported to have been used successfuly in obesity therapy. The active compounds contained in Jati Belanda leaves and soybeans can act as a lipase inhibitor. The purpose of this study was to determine the lipase activity of the ethanol extract of Detam 1 soybeans (EEDS), of Jati Belanda leaves (EEJB), of the two extracts combined, and of the fractions of individual extract, using the standard methods and their modifications. The lipase activity of EEDS, of EEJB, of the combined extracts, and of the ethyl acetate-, water-, and n-hexane-fractions, were tested using the Lipase Liquicolor kit (HUMAN囚), spectrophotometry at $580 \mathrm{~nm}$, and the modified methods: 96 well plate, microplate reader $630 \mathrm{~nm}$. It can be concluded that: the highest lipase activity was found in the combined extracts at the ratio of EEDS: EEJB = 1:2, either using the standard methods or the modified methods; fractions containing the highest activity of lipase were the KD water fraction (100 ppm) and the JB water fraction (100 ppm). The lipase activity of the JB water fraction was higher than that of the KD water fraction.

Keyword: lipase activity, soy Detam 1, Jati Belanda

\section{PENDAHULUAN}

Lipase pankreas adalah enzim yang terpenting dalam mencerna dan absorbsi trigliserida dalam makanan (Embleton \& Pouton, 1997). Enzim ini dapat larut dalam air dan bekerja dengan mengkatalisis hidrolisis ikatan ester dalam substrat lipid yang tidak larut air seperti trigliserida rantai panjang, dengan demikian, lipase tergolong dalam enzim esterase (Medline, 2011).

Lipase berbeda dari esterase lainnya karena mempunyai sisi penempelan hidrofobik (Tietz \& shuey, 1993).

Human pancreatic lipase (HPL), merupakan enzim utama yang bertanggung jawab dalam memecah lemak dalam saluran pencernaan manusia, dengan mekanisme kerja mengubah substrat trigliserida yang terdapat dalam lemak makanan menjadi monogliserida dan asam lemak bebas (Svendsen, 2000).
Salah satu pendekatan terapi dalam menurunkan kejadian obesitas adalah memperlambat absorbsi asam lemak dengan cara menginhibisi enzim lipase pankreas dalam saluran pencernaan (Ballinger \& Peikin, 2002). Inhibitor enzim lipase pankreas dilaporkan telah berhasil digunakan dalam pengelolaan terapi obesitas. Inhibitor lipase yang sudah banyak digunakan adalah Orlistat, turunan dari Lipstatin ter-hidrogenasi, dan turunan dari Streptomyces toxitricinin (Ballinger \& Peikin, 2002). Selain itu masih banyak zat aktif dalam tanaman berkhasiat seperti teh hijau, Jati Belanda dan kedelai yang dapat berfungsi sebagai inhibitor lipase (Higaki, 2003).

Senyawa aktif dalam beberapa tanaman berkhasiat, derivat substansi dalam tanaman, asam amino dan metabolit sekunder dari tanaman berpotensi menjadi suplemen pangan (Raskin et al., 2002). Zat aktif dalam beberapa tanaman dapat menjadi sumber antiobesitas melalui mekanisme 
inhibisi enzim lipase pankreas. Zat aktif tersebut antara lain: saponin, polifenol, dan terpenoid (Drent $e t$ al., 1995; Yamamoto, 2000 \& Reaven, 2001).

Penelitian Iswantini et al. (2011) menyebutkan bahwa ekstrak metanol daun Jati Belanda varietas Bogor mempunyai aktifitas inhibisi enzim lipase pankreas diisolasi dari Rhizopus arrhizus, sedangkan ekstrak kloroformnya dapat meningkatkan aktifitas enzim lipase (Iswantini, 2011), akan tetapi perlu diingat bahwa aktifitas zat aktif dalam suatu tanaman dipengaruhi oleh daerah dan unsur-unsur dalam tanah tempat tumbuhnya.

Kedelai (Glycine max L.Merr) varietas Detam 1 adalah kedelai varietas unggul yang mempunyai kadar protein yang lebih tinggi, yaitu $45,12 \%$ berat bijinya dan mempunyai kadar lemak yang lebih rendah dibanding varietas lainnya. Diperkirakan kedelai Detam 1 mengandung lebih banyak zat aktif yang berada dalam kandungan bijinya.

Hasil penelitian sebelumnya, didapat bahwa formula terbaik dalam menginhibisi enzim lipase pankreas secara in vitro adalah kombinasi antara 10 mg ekstrak etanol kedelai Detam 1 (EEKD) dan 20 mg ekstrak etanol daun Jati Belanda (EEJB) (Hidayat, 2012). Penelitian in vivo yang dilakukan terhadap tikus Wistar jantan dengan perlakuan sebelas jenis ekstrak kedelai selama empat belas hari, menunjukkan bahwa ekstrak metanol kedelai varietas Detam 1 dengan dosis 20 mg/ekor $(p=0,022)$, terbukti signifikan menurunkan berat badan $(\mathrm{p}=0,020)$ semula $249 \pm 21,38 \mathrm{~g}$ menjadi $221 \pm 27,30 \mathrm{~g}$ (Hidayat et al., 2009). Ekstrak etanol biji kedelai Detam 1 terbukti mengandung fenolik, flavonoid, triterpenoid, steroid, saponin, kuinon dan tanin, namun tidak mengandung alkaloid. Ekstrak etanol daun Jati Belanda terbukti mengandung fenolik, flavonoid, triterpenoid, kuinon dan tanin, namun tidak mengandung alkaloid, steroid, saponin (Hidayat dkk, 2012).

Tujuan penelitian ini adalah mengetahui aktivitas lipase dari ekstrak etanol kedelai Detam 1, daun Jati Belanda, kombinasi serta fraksionasinya menggunakan metode standar dan modifikasi.

\section{BAHAN DAN METODE \\ Bahan dan alat penelitian}

Bahan yang dipilih dalam penelitian ini adalah biji kedelai unggulan varietas Detam 1 yang ditanam di perkebunan Balitkabi Malang dan daun Jati Belanda yang ditanam di perkebunan Bumi Herbal Dago yang selanjutnya dibuat ekstrak etanol kedelai Detam 1 (EEKD) dan ekstrak etanol Jati Belanda (EEJB).

Bahan kimia yang digunakan untuk ekstraksi meliputi etanol teknis 95\%, aquadest, laktosa, kit uji lipase in vitro lipase liquicolor, yang terdiri dari buffer dan substrat. Buffer $\mathrm{pH}$ 8,0 mengandung goods buffer $40 \mathrm{mmol} / \mathrm{L}$, taurodesoxycholate $3,4 \mathrm{mmol} / \mathrm{L}$, desoxycholate $6,4 \mathrm{mmol} / \mathrm{L}$, kalsium klorida 12 $\mathrm{mmol} / \mathrm{L}$, colipase $1,7 \mathrm{mmol} / \mathrm{L}$, natrium azida $0,095 \%$; Sedangkan bahan substrat $\mathrm{pH} \quad 4,0$ mengandung tartrate buffer $1,5 \mathrm{mmol} / \mathrm{L}$, taurodesoxycholate 3,4 $\mathrm{mmol} / \mathrm{L}$, colour substrate $0,13 \mathrm{mmol} / \mathrm{L}$, natrium azida $0,095 \%$.

Alat yang digunakan dalam penelitian ini adalah beaker glass, sokletasi, tabung eppendorf, tabung vial $1 \mathrm{~mL}$, penangas air, corong, labu ukur, batang pengaduk, labu evaporator pembuat ekstrak, alat-alat gelas, maserator, autoklaf, cuvet spektro, mikropipet, yellow up \& blue tip, kamera digital, alat sentrifuge, timbangan analitik, stopwatch, termometer, spektrofotometer, oven, waterbath, microplate reader serta perangkat komputer.

\section{Tempat dan waktu penelitian}

Penelitian dilaksanakan di Laboratorium Pusat Penelitian Ilmu Kedokteran, Universitas Kristen Maranatha Bandung, Lembaga Ilmu Pengetahuan Indonesia-Bandung; Laboratorium Penelitian dan Pelayanan-Jurusan Kimia FMIPA, Universitas Padjadjaran-Bandung.

\section{Tahap penelitian}

Penelitian tahap pertama meliputi ekstraksi etanol biji Kedelai varietas Detam 1 dan ekstraksi etanol daun jati Belanda varietas Bumi Herbal Dago. Selanjutnya dilakukan fraksinasi dan uji aktivitas inhibisi enzim lipase pankreas secara in vitro

\section{Ekstraksi Etanol Biji Kedelai Detam 1 dan Daun Jati Belanda var Bumi Herbal Dago}

Proses ekstraksi menggunakan metode maserasi sederhana. Tahap ekstraksinya ditunjukkan pada Gambar 1 di bawah ini:

Biji kedelai Detam $1(500 \mathrm{~g})$ \&

Daun Jati Belanda (500 g)

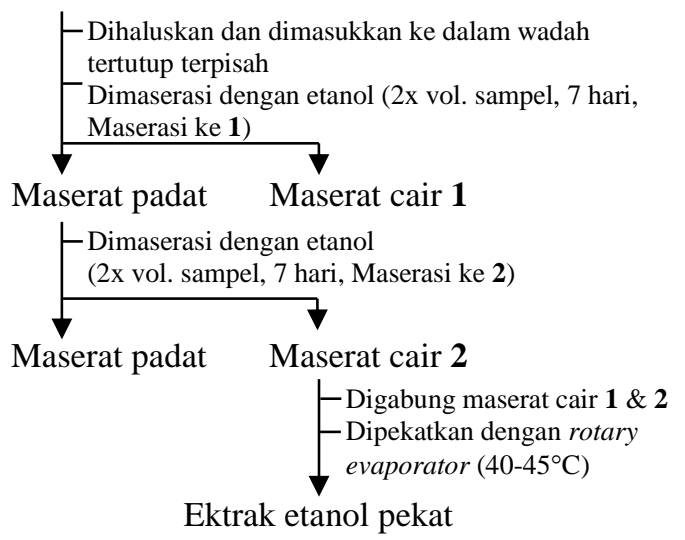

Gambar 1. Skema Pembuatan EEKD dan EEJB

Fraksionasi n-Heksana, Etil Asetat dan Air dari Kedelai Detam 1 dan Jati Belanda (Harborne,1987).

Tahap fraksionasi $n$-heksana, etil asetat dan fraksi air dari kedelai dan Jati Belanda ditunjukkan pada skema di bawah ini: 


\section{Ektrak Etanol pekat

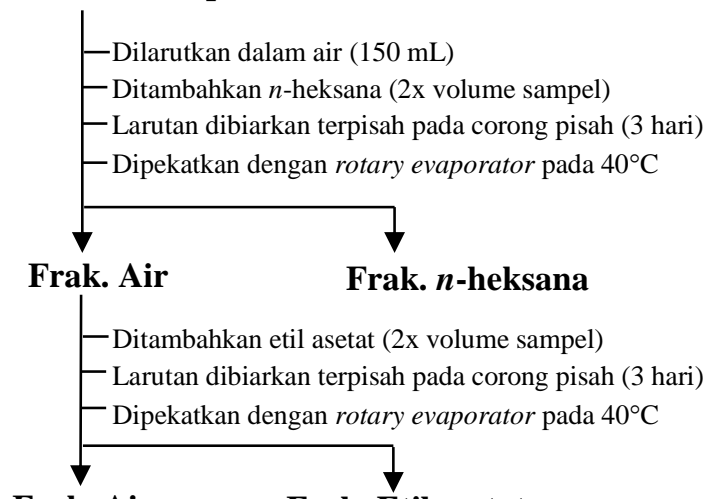 \\ Frak. Air \\ Frak. Etil asetat}

Gambar 2. Skema pembuatan fraksi etil asetat, air dan $n$ heksana biji kedelai Detam 1 dan daun Jati Belanda

\section{Uji Aktifitas Enzim Lipase Pankreas}

Aktifitas lipase ditentukan dengan metode kolorimetri dengan kit Lipase Liquicolor (HUMAN®) yang selanjutnya dibaca menggunakan spektrofotometer pada panjang gelombang $580 \mathrm{~nm}$.

\section{Prinsip Kerja kit Lipase Liquicolor (HUMAN®)}

Produk sintetis substrat lipase (1,2-0-dilaurylrac-glycero-3-glutaric acid-(6-methylresorufin)ester) ditambahkan pada mikroemulsi akan terdegradasi secara spesifik oleh lipase dengan adanya ko-lipase dan asam empedu. Kombinasi lipase dan asam empedu memastikan penentuan spesifik dari lipase pankreas tanpa reaksi lain dari enzim lipolisis atau esterase. Komposisi reagen telah dioptimasi dengan akurat sehingga tidak akan ada efek serum. Metil resorufin ester terbentuk secara spontan dari metil resorufin. Absorbansi warna merah muda sebanding dengan peningkatan aktivitas lipase dalam sampel. Prinsip Kerja: Reaksi katalisis Lipase

\section{Prosedur Uji Aktifitas Lipase Metode Standar:}

Sebanyak $20 \mu \mathrm{L}$ aquadest dimasukkan ke dalam sebuah cuvet spektro, kemudian ditambahkan $1000 \mu \mathrm{L}$ buffer untuk membuat blanko. Campuran dihomogenkan dengan cara digoyang perlahan lalu diinkubasi dalam waterbath selama 2 menit. Kemudian ditambahkan substrat sebanyak $250 \mu \mathrm{L}$. Diinkubasi dalam waterbath selama 2 menit pada suhu $37^{\circ} \mathrm{C}$. Setelah itu dibaca pada spektrofotometer dengan panjang gelombang $580 \mathrm{~nm}$. Perubahan aktifitas enzim yang terjadi dicatat pada menit ke 1, 2 dan 3 .

Selanjutnya dilakukan pemeriksaan standar atau blanko dan tujuh jenis sampel. Sebanyak $20 \mu \mathrm{L}$ aquadest dimasukkan ke dalam delapan buah cuvet spektro, lalu masing-masing ditambahkan kalibrator, sampel 1: EEKD-EEJB = 2:1 sebanyak $20 \mu \mathrm{L}$, sampel 2: EEKD-EEJB = 1:2 sebanyak $20 \mu \mathrm{L}$, sampel 3: EEKD-EEJB = 1:1 sebanyak $20 \mu \mathrm{L}$, sampel 4: EEKD sebanyak $20 \mu \mathrm{L}$, sampel 5: EEJB sebanyak $20 \mu \mathrm{L}$, sampel 6: kontrol pembanding Orlistat sebanyak 20 $\mu \mathrm{L}$ dan sampel 7: kontrol pembanding Simvastatin sebanyak $20 \mu \mathrm{L}$. Selanjutnya ditambahkan $100 \mu \mathrm{L}$ buffer pada tiap cuvet dan diinkubasi dalam waterbath selama 1-5 menit.

Pada campuran ditambahkan $25 \mu \mathrm{L}$ substrat, dihomogenkan dan diinkubasi dalam waterbath selama 1-5 menit. Absorbansi dibaca pada spektrofotometer dengan panjang gelombang $580 \mathrm{~nm}$ dan suhu $37^{\circ} \mathrm{C}$. Pengukuran ini harus dilakukan sesegera mungkin, karena campuran mudah bereaksi dengan udara (absorbansi akan meningkat). Karakteristik performans Linearitas diatur antara 1200 U/1. Selanjutnya perubahan aktifitas enzim yang terjadi dicatat pada menit ke 1, 2 dan 3 kemudian dihitung menggunakan rumus yang ada. Aktifitas penghambatan lipase (lipase inhibitor) ditunjukkan dari hasil perhitungan menurut rumus tersebut. Kadar referensi: < $60 \mathrm{U} / 1$ (NCCLS). Untuk memastikan kesahihan hasil data tiap sampel diperiksa tiga kali (triplo). Rumus Perhitungan Aktifitas Lipase yang terbentuk:

Lipase $(\mathrm{U} / \mathrm{L})=\frac{(\text { A sampel }- \text { A blanko })}{(\text { A CAL }- \text { A blanko })} \times$ Cons. CAL $(\mathrm{U} / \mathrm{L})$

Dengan dasar pemikiran bahwa pengukuran absorbansi harus dilakukan sesegera mungkin, waktu yang tepat, serta jumlah banyak sekaligus, maka dilakukan modifikasi prosedur uji lipase inhibitor ini. Selain itu sampel penelitian ini berupa ekstrak tanaman berkhasiat, sehingga dilakukan penyesuaian prosedur. Modifikasi pengujian ini menggunakan 96 well plate, hanya menggunakan sedikit reagen dan dibaca menggunakan microplate reader dengan panjang gelombang yang paling mendekati panduan, yaitu $630 \mathrm{~nm}$. Modifikasi prosedur selengkapnya seperti yang tercantum di bawah ini.

\section{Prosedur Uji Aktifitas Lipase Metode Modifikasi Persiapan preparasi EEKD dan EEJB}

Sebanyak $1 \mathrm{mg}$ EEKD dan EEJB ditimbang dan masing-masing dimasukkan ke dalam tabung mikro. Selanjutnya dilarutkan dalam $1 \mathrm{~mL}$ etanol re-destilasi dan dihomogenkan. Campuran diencerkan, dibuat konsentrasi 100, 50, 25, dan 12,5 ppm.

\section{Preparasi Sampel Fraksi Kedelai Detam 1 dan Jati Belanda}

Sebanyak $1 \mathrm{mg}$ fraksi air, etil asetat dan $n$ heksana kedelai Detam 1 dan Jati Belanda ditimbang dan masing-masing dimasukkan ke dalam microtube. Selanjutnya dilarutkan dalam $1 \mathrm{~mL}$ pelarut (fraksi airaquabidest, fraksi etil asetat-metanol, dan fraksi $n$ heksana- $n$-heksana) lalu dihomogenkan, campuran diencerkan, dibuat konsentrasi 100, 50, 25, dan 12,5 ppm.

\section{Pengujian Aktifitas Lipase}

Sebanyak $65 \mu \mathrm{L}$ aquabidest steril dimasukkan ke dalam microplate 96 well kemudian ditambahkan 10 
$\mu \mathrm{L}$ sampel (dengan berbagai pengenceran). Selanjutnya ditambahkan $5 \mu \mathrm{L}$ calibrator (CAL) dan $100 \mu \mathrm{L}$ buffer (BUF). Campuran dihomogenkan, lalu diinkubasi selama 1-5 menit. Setelah itu ditambahkan substrat $25 \mu \mathrm{L}$, dicampurkan dan diinkubasi selama 2 menit dalam oven pada suhu $37^{\circ} \mathrm{C}$. Absorbansi dibaca menggunakan microplate reader pada panjang gelombang $630 \mathrm{~nm}$ pada menit ke-0, 2, 4, 6, 8, 10, 15, 20, 25. Kadar referensi kalibrator lipase adalah 110 U/1 (Cobas, 2014).

\section{HASIL DAN PEMBAHASAN}

Tabel 1. Hasil pemeriksaan aktifitas lipase sampel tunggal EEKD, EEJB, sampel kombinasi dan pembanding menggunakan metode standar

\begin{tabular}{lccccc}
\hline \multicolumn{1}{c}{ SAMPEL } & $\Delta \mathbf{0 - 1}$ & $\boldsymbol{\Delta} \mathbf{1 - 2}$ & $\boldsymbol{\Delta} \mathbf{2 - 3}$ & Rerata & $\begin{array}{c}\text { Perhitungan Aktifitas } \\
\text { Lipase (U/) }\end{array}$ \\
\hline 1. EEKD 20 mg: EEJB 10 mg & 0,005 & 0,011 & 0,001 & 0,005667 & 38,88889 \\
2. EEKD 10 mg: EEJB 20 mg & 0,017 & 0,009 & 0,007 & 0,011 & 83,33333 \\
3. EEKD 10 mg: EEJB 10 mg & 0,002 & 0,024 & 0,003 & 0,009667 & 72,22222 \\
4. EEKD 20 mg & 0,004 & 0,008 & 0,004 & 0,005333 & 36,11111 \\
5. EEJB 20 mg & 0,005 & 0,007 & 0,007 & 0,006333 & 44,44444 \\
6. Orlistat & 0,032 & 0,032 & 0,032 & 0,032 & 258,3333 \\
7. Simvastatin & 0,018 & 0,018 & 0,018 & 0,018 & 141,6667 \\
Kalibrator & 0,073 & 0,073 & 0,073 & 0,073 & \\
Blanko & 0,001 & 0,001 & 0,001 & 0,001 & \\
\hline
\end{tabular}

Tabel 2. Hasil pemeriksaan dan perhitungan aktifitas lipase dengan penambahan inhibitor kombinasi EEKD dan EEJB dengan metode modifikasi pada menit ke 25

\begin{tabular}{|c|c|c|c|c|c|c|c|}
\hline \multirow{2}{*}{ SAMPEL } & \multicolumn{4}{|c|}{ Konsentrasi (ppm) } & \multirow{2}{*}{ K. Pelarut } & \multirow{2}{*}{ Kal } & \multirow{2}{*}{ Blanko } \\
\hline & 100 & $\mathbf{5 0}$ & 25 & 12,5 & & & \\
\hline EEKD : EEJB (1:1) & 0,057 & 0,056 & 0,054 & 0,06 & 0,05 & 0,059 & 0,053 \\
\hline EEKD : EEJB (1:1) & 0,057 & 0,064 & 0,057 & 0,059 & 0,057 & 0,059 & 0,055 \\
\hline Rerata & 0,057 & 0,06 & 0,0555 & 0,0595 & 0,054 & 0,059 & 0,054 \\
\hline Hasil Lipase (U/I) & 66 & 132 & 33 & 121 & & & \\
\hline EEKD : EEJB (1:2) & 0,052 & 0,051 & 0,05 & 0,047 & & 0,051 & 0,048 \\
\hline EEKD : EEJB (1:2) & 0,052 & 0,053 & 0,051 & 0,049 & & 0,048 & 0,047 \\
\hline Rerata & 0,052 & 0,052 & 0,0505 & 0,048 & & 0,0495 & 0,0475 \\
\hline Hasil Lipase (U/l) & 247,5 & 247,5 & 165 & 27,5 & & & \\
\hline EEKD : EEJB (2:1) & 0,056 & 0,059 & 0,055 & 0,054 & & 0,055 & 0,051 \\
\hline EEKD : EEJB (2:1) & 0,058 & 0,055 & 0,056 & 0,056 & & 0,056 & 0,052 \\
\hline Rerata & 0,057 & 0,057 & 0,0555 & 0,055 & & 0,056 & 0,052 \\
\hline Hasil Lipase (U/I) & 151,3 & 151,3 & 110 & 96,25 & & & \\
\hline
\end{tabular}

Tabel 3. Hasil absorbansi sampel fraksi etil asetat, air dan $n$-heksana kedelai Detam 1 dan Jati Belanda dan pembanding Orlistat dengan modifikasi metode pada menit ke 25

\begin{tabular}{|c|c|c|c|c|c|c|c|c|c|c|c|c|}
\hline \multirow{2}{*}{$\begin{array}{l}\text { Dosis } \\
(\mathrm{ppm})\end{array}$} & \multicolumn{6}{|c|}{ Kedelai Detam 1} & \multicolumn{6}{|c|}{ Jati Belanda } \\
\hline & $\begin{array}{c}\text { Etil } \\
\text { asetat }\end{array}$ & Air & Heksana & $\begin{array}{c}\text { Etil } \\
\text { asetat }\end{array}$ & Air & Heksana & Air & $\begin{array}{c}\text { Etil } \\
\text { asetat }\end{array}$ & Heksana & Air & $\begin{array}{c}\text { Etil } \\
\text { asetat }\end{array}$ & Heksana \\
\hline 100 & 0,127 & $\mathbf{0 , 0 7 3}$ & 0,073 & 0,149 & 0,227 & 0,122 & 0,388 & 0,17 & 0,153 & 0,157 & 0,143 & 0,15 \\
\hline 50 & 0,092 & 0,058 & 0,218 & 0,108 & 0,058 & 0,096 & 0,266 & 0,165 & 0,103 & 0,085 & 0,094 & 0,113 \\
\hline 25 & 0,071 & 0,056 & 0,066 & 0,144 & 0,129 & 0,073 & 0,191 & 0,279 & 0,086 & 0,116 & 0,098 & 0,085 \\
\hline 12,5 & 0,061 & 0,061 & 0,059 & 0,12 & 0,084 & 0,075 & 0,144 & 0,078 & 0,07 & 0,072 & 0,059 & 0,084 \\
\hline & ORL. & & ORL & Blanko 1 & & 3lanko 2 & Kal 1 & & & & & \\
\hline 100 & 1,623 & & 1,385 & 0,05 & & 0,048 & 0,055 & & & & & \\
\hline $\mathbf{5 0}$ & 0,733 & & 0,632 & 0,048 & & 0,047 & 0,066 & & & & & \\
\hline 25 & 0,362 & & 0,4 & & & & & & & & & \\
\hline 12,5 & 0,287 & & 0,257 & & & & & & & & & \\
\hline
\end{tabular}

Pada Tabel 1 menunjukkan bahwa yang memiliki aktivitas lipase tertinggi adalah sampel kontrol pembanding Orlistat, 258,3333 U/L. Hasil pemeriksaan sampel ekstrak, kadar lipase tertinggi didapatkan pada sampel kombinasi EEKD $10 \mathrm{mg}$ : EEJB $20 \mathrm{mg}$. Selanjutnya dilakukan pengujian pada sampel kombinasi EEKD dan EEJB dengan 
modifikasi metode. Hasilnya ditunjukkan pada Tabel 2 dan Gambar 3.

Dari hasil perhitungan kadar lipase Tabel 2 serta pengamatan Gambar 3, terlihat bahwa kadar lipase tertinggi didapat pada sampel kombinasi EEKD: $\mathrm{EEJB}=1: 2$ pada konsentrasi 100 ppm, yaitu 247,5 U/1. Hasil ini ternyata sesuai dengan hasil pengujian menggunakan metode standar. Tahap selanjutnya dilakukan pengujian pada sampel fraksi etil asetat, air dan $n$-heksana kedelai Detam 1 dan Jati Belanda dan Orlistat. Hasilnya ditunjukkan pada Tabel 3 dan Gambar 4.

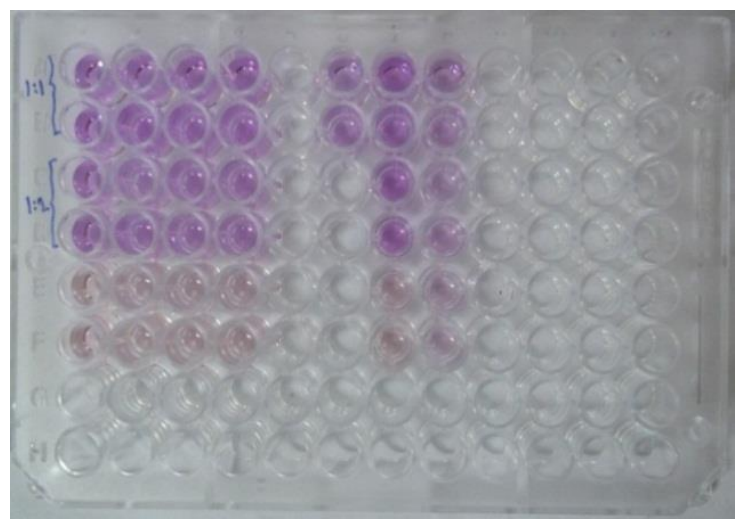

Gambar 3. Hasil pemeriksaan sampel kombinasi EEKD dan EEJB dengan metode modifikasi menit ke 25

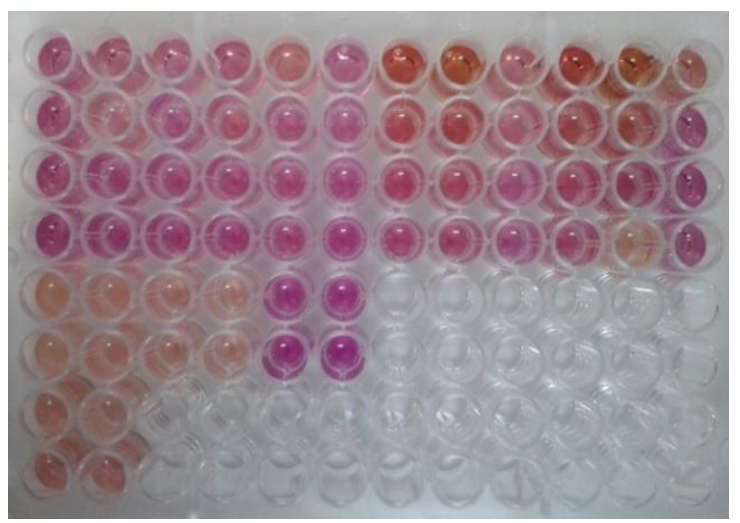

Gambar 4. Hasil pemeriksaan sampel fraksi etil asetat, air dan $n$-heksana kedelai Detam 1 dan Jati Belanda dengan metode modifikasi menit ke 25

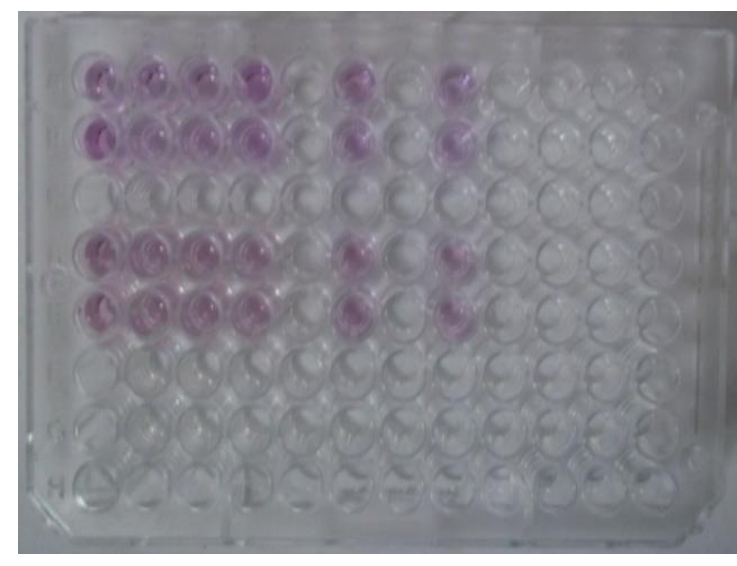

Gambar 5. Hasil pemeriksaan sampel fraksi air kedelai Detam 1 dan Jati Belanda menit ke 25

Berikut dilakukan penghitungan aktivitas lipase sampel fraksi asetat, air dan $n$-heksana kedelai Detam 1 dan Jati Belanda dan Orlistat dengan metode modifikasi. Hasilnya dapat dilihat pada Tabel 4 di bawah ini.

Dari data Tabel 3, 4 dan Gambar 3 disimpulkan bahwa yang terbaik adalah fraksi air kedelai Detam 1 pada 100 ppm dan fraksi air Jati Belanda 100 ppm. Selanjutnya dilakukan pengujian fraksi air dari kedelai Detam 1 dan Jati Belanda, dapat dilihat pada Tabel 5 dan Gambar 5 di bawah ini.

Dari data Tabel 5 dan Gambar 5 menunjukkan bahwa aktivitas lipase fraksi air Jati Belanda 100 ppm adalah yang paling tinggi (953U/1), jauh lebih tinggi daripada fraksi air Kedelai Detam 1 (151,3 U/1), sedangkan pada konsentrasi 25 ppm kadar lipase fraksi air Kedelai Detam 1 sedikit lebih tinggi daripada Jati Belanda.

Aktivitas lipase tertinggi didapatkan pada sampel kombinasi EEKD $10 \mathrm{mg}$ : EEJB $20 \mathrm{mg}$, baik menggunakan metode standar maupun metode modifikasi. Hasil sampel kombinasi secara umum lebih baik daripada sampel tunggal. Hal ini mungkin disebabkan adanya sinergisme antara EEKD dan EEJB yang memberikan potensi peningkatan aktivitas total yang lebih tinggi dibandingkan dengan ekstrak tunggalnya.

Tabel 4. Hasil perhitungan aktifitas lipase (dalam U/L) dari fraksi etil asetat, air dan $n$-heksana dari kedelai Detam 1 dan Jati Belanda serta pembanding Orlistat dengan metode modifikasi

\begin{tabular}{|c|c|c|c|c|c|c|c|}
\hline \multirow{2}{*}{$\begin{array}{c}\text { Konsentrasi } \\
(\text { ppm) }\end{array}$} & \multicolumn{3}{|c|}{ Kedelai Detam (KD) } & \multicolumn{3}{|c|}{ Jati Belanda (JB) } & \multirow{2}{*}{ Orlistat } \\
\hline & Etil aseatat & Air & Heksana & Etil aseatat & Air & Heksana & \\
\hline 100 & 918,3721 & 1041,163 & 503,9535 & 2294,651 & 1107,674 & 1056,512 & 14896,05 \\
\hline 50 & 529,5349 & 99,76744 & 1112,791 & 1302,093 & 831,3953 & 611,3953 & 6490 \\
\hline 25 & 606,2791 & 452,7907 & 217,4419 & 1076,977 & 1435,116 & 381,1628 & 3404,884 \\
\hline 12,5 & 432,3256 & 248,1395 & 191,8605 & 611,3953 & 207,2093 & 294,186 & 2289,535 \\
\hline
\end{tabular}


Tabel 5. Hasil pemeriksaan dan perhitungan aktivitas lipase sampel fraksi air kedelai Detam 1 dan Jati Belanda pada menit ke 25

\begin{tabular}{|c|c|c|c|c|c|c|}
\hline & \multicolumn{4}{|c|}{ Konsentrasi (ppm) } & \multirow{2}{*}{ Kal } & \multirow{2}{*}{ Blanko } \\
\hline & 100 & 50 & 25 & 12.5 & & \\
\hline Jati & 0,051 & 0,062 & 0,049 & 0,059 & 0,048 & 0,048 \\
\hline Belanda & 0,07 & 0,047 & 0,049 & 0,052 & 0,05 & 0,047 \\
\hline Lipase: & 953,3 & 513,3 & 110 & 586,7 & & \\
\hline Kedelai & 0,064 & 0,063 & 0,061 & 0,061 & 0,059 & 0,058 \\
\hline Detam 1 & 0,065 & 0,074 & 0,067 & 0,063 & & \\
\hline Lipase: & 151,3 & 261,3 & 137,5 & 82,5 & & \\
\hline
\end{tabular}

Berdasarkan teori terbukti bahwa kombinasi yang tepat dari dua atau lebih inhibitor menghasilkan total inhibitor yang dapat mengakibatkan penghambatan sinergis peroksidasi lipid. Sinergisme adalah efek kooperatif suatu senyawa dengan senyawa lainnya yang menghasilkan peningkatan aktivitas dari jumlah masing-masing aktivitas (Papas, 1999).

Kalibrator (CAL) dalam reagen bertindak sebagai enzim standar yang akan berkompetisi dengan sampel. Sampel umumnya berupa serum atau plasma heparin yang telah mengandung lipase, sedangkan pada penelitian ini sampel berupa ekstrak tanaman berkhasiat sehingga perlu direaksikan terlebih dahulu dengan Buffer (BUF) dengan cara diinkubasi. Hal ini mengacu pada penelitian sejenis yang menggunakan sampel ekstrak tanaman (Iswantini et al., 2005).

Fraksi yang mengandung aktifitas lipase paling tinggi adalah fraksi air kedelai Detam 1 pada 100 ppm dan fraksi air Jati Belanda 100 ppm. Hal ini karena lipase mempunyai sisi penempelan hidrofobik. Lipase berbeda dari esterase lainnya karena adanya sisi penempelan hidrofobik ini dan $\mathrm{pH}$ optimal terjadinya reaksi adalah antara 7,5 hingga 10,0. Pemeriksaan spesifik untuk lipase membutuhkan trigliserida sebagai substrat selain colipase (berupa protein yang larut air, tahan pemanasan dan berperan sangat penting dalam aktivitas lipase), garam empedu sekunder dan $\mathrm{Ca}^{2+}$ (Tietz, 1993).

Buffer dalam kit ini mempunyai $\mathrm{pH} \quad 8,0$ mengandung antara lain taurodesoxycholate, desoxycholate, calcium chloride, dan colipase (sebagai kofaktor) (Cattozzo, 2001) dan dengan pemberian ekstrak kedelai Detam 1 dan Jati Belanda akan terbentuk inhibitor lipase dan asam empedu. Inhibitor lipase ini akan menghambat enzim (CAL) sehingga proses lipolisis atau lipoesterase dihambat. Pada tahap selanjutnya baru direaksikan dengan substrat (SUB) yang sedianya akan berikatan dengan kalibrator (CAL) yang kompetitif dengan sampel.

Aktivitas lipase dalam fraksi air Jati Belanda 100 ppm sangat tinggi (953 U/l), jauh lebih tinggi daripada fraksi air kedelai Detam 1 (151,3 U/1). Aktivitas lipase tidak bergantung dari jumlah substrat, tapi bergantung dari konsentrasi interface (kontak) substrat yang diukur dalam luas area permukaan kontak emulsi $\mathrm{m}^{2} / \mathrm{L}$ dan kualitas dari interface antara substrat yang tidak larut dan fase air. Pada kontak inilah lipase bekerja menghidrolisis substrat (Cattozzo, 2001).
Keterbatasan dalam penelitian ini, pada beberapa hasil pemeriksaan sampel fraksi seperti misalnya pada Tabel 5, menunjukkan hasil yang kurang konsisten, aktivitas fraksi air Jati Belanda konsentrasi 12,5 ppm (586,7 U/1 ) lebih tinggi daripada 50 ppm (513,3 U/l) dan 25 ppm (110 U/l), dan fraksi air Kedelai Detam 1 konsentrasi 50 ppm (261,3 U/l) lebih tinggi daripada konsentrasi $100 \mathrm{ppm}$ (151,3 U/l). Hal ini mungkin disebabkan karena adanya gelembung yang terbentuk saat menambahkan buffer pada microplate well, yang sulit sekali dihindari. Hal ini disebabkan karena buffer mengandung natrium azida. Selain itu sediaan substrat merupakan larutan dengan mikrogranul yang sulit dijadikan homogen. Hal-hal tersebut dapat menyebabkan peningkatan hasil aktivitas yang dibaca oleh microplate reader, akan tetapi aktivitas lipase dapat disimpulkan berdasarkan hasil pengukuran yang dilakukan dua kali untuk meminimalkan kesalahan.

\section{KESIMPULAN}

Aktivitas lipase tertinggi didapatkan pada sampel dengan kombinasi ekstrak etanol kedelai Detam 1 dan ekstrak etanol Jati Belanda perbandingan 1:2, baik menggunakan metode standar maupun metode modifikasi, sedangkan untuk fraksi yang mengandung aktivitas lipase paling tinggi adalah fraksi air kedelai Detam 1 pada 100 ppm dan fraksi air Jati Belanda 100 ppm.

\section{UCAPAN TERIMA KASIH}

Kami mengucapkan terima kasih kepada Hibah Bersaing 2013 Dikti, Republik Indonesia atas dukungan dana untuk terlaksananya penelitian ini. Kami haturkan terima kasih kepada Ibu Riezki Amalia, M.Si, Ibu Susianti, A.Md, di Laboratorium Penelitian dan Pelayanan-Jurusan Kimia UNPAD atas bantuannya dalam pengerjaan penelitian ini.

\section{DAFTAR PUSTAKA}

Balinger, A. \& Peikin, S.I.R. (2002). Orlistat: Its current status as an antiobesity drug. Eur. J. Pharm. Sci., 440, 109-117. Doi: 10.1016/S00142999 (02)01422-X.

Bennett, T.P. \& Frieden, E. (1969). Worthington publication which was originally published in 1972 as the Manual of Clinical Enzyme Measurements: Modern Topics in Biochemistry, p. 43-45, Macmillan, London. 
Cattozzo, G., Franzini, C. \& d'Eril, G.M. (2001). Commutability of Calibration and Control Materials for Serum Lipase Enzymes and Protein Markers. Clinical Chemistry, 47(12), 2108-2113.

Cobas, Roche/Hitachi Analyzers (2014). Calibrator for automated systems. Standardized with C.f.a.s masterlot 162490.

Drent, M.I., Larsson, I., William-Olsson, T., Quaade, F., Czubayko, F., von Bergmann, $\mathrm{K}$ et al. (1995). Orlistat (Ro 18-0647), a lipase inhibitor, in the treatment oh human obesity; a multiple dose study. Int. J. Obes. Relat. Metab. Disord., 19, 221-226.

Harborne, J.B. (1987). Metode Fitokimia. Penuntun Cara Modern menganalisis Tumbuhan. Terbitan Kedua. Penerbit ITB Bandung.

Hidayat, M., Kurnia, D., Sujatno, M., Sutadipura, N. \& Setiawan (2010). Perbandingan kandungan makronutrisi dan isoflavon dari biji, tempe dan ekstrak kedelai Detam 1 dan Wilis serta potensinya dalam menurunkan bobot badan. Bionatura Jurnal Ilmu Hayati dan Fisik, 12(1), 5-13.

Hidayat, M., Soeng, S., \& Prahastuti, S. (2012). Characteristics of Combination of Ethanol Extract Detam 1 Soybean (Glycine max L.merr) and Ethanol Extract of Jati Belanda leaves (Guazuma ulmifolia) in potential inhibition of Pancreas Lipase Enzyme. Poster. International Seminar on Natural Products.

Hidayat, M., Sujatno, M., Sutadipura, N., \& Setiawan (2009). Effect Several Soybean (Glycine Max L. Merr) Extracts To Food Intake, Body Weight And Cholecystokinin Plasma In Rats. Majalah Ilmu Faal Indonesia, 8 (3), 151-158.

Higaki, S. (2003). Lipase inhibitor for the treatment of acne. J. Mol. Cat. B: Enzymatic, 22, 377-384. Doi: 10.1016/S1381-1177(03)00053-5.

Iswantini, D., et al. (2005). Ekstrak Bangle sebagai pelangsing: aktivitasnya terhadap serum lipase. Prosiding Seminar Nasional Kimia Bahan Alam $\mathrm{XV}$, Jogjakarta, p. 8-17.

Iswantini, D., Silitonga, R.F., Martatilofa, E., \& Darusman, L.K. (2011). Zingiber cassumunar, Guazuma ulmifolia, and Murraya paniculata Extracts as Antiobesity: In Vitro Inhibitory Effect on Pancreatic Lipase Activity. Hayati, Journal of Biosciences 18(1), ISSN: 1978-3019.

Medline. Human Pancreatic Lipase. Diunduh tanggal 16 September 2011. Tersedia di http://www.websters-onlinedictionary. org/definitions/Humanpancreaticlipase.

Papas, A.M. (1999). Antioxidant, Status, Diet, Nutrition, and Health. Washington DC, CRC Press.

Raskin, I., David, M.R., Slavco, K., Nebosja, I., Alexander, P., Nikolai, B., Anita, B., Diego, A.M., Christophe, R., Yakoby, N., Joseph, M.O'Neal., Teresa, C., Ira, P., \& Bertold, F. (2002). Plants and human health in the twenty- first century. TRENDS in Biotechnology, 2(12), 522-531.

Reaven, G., Segal, K., Hauptman, J., Boldrin, M., \& Lucas, C. (2001). Effect of Orlistat-assisted weight loss in decreasing coronary heart disease risk in patients with syndrome x. Am. J. Cardiol., 87, 827-831. doi: 101248/ bpb.26.854.

Soberón-Chávez, G., \& Palmeros, B. (1994). Pseudomonas lipases: molecular genetics and potential industrial applications. Crit. Rev. Microbiol. 20(2), 95-105.

Svendsen, A. (2000). Lipase protein engineering. Biochem. Biophys. Acta, 1543(2), 223-228.

Tietz', N.W. \& Shuey, D.F. (1993). Lipase in Serumthe Elusive Enzyme: An Overview. Clin. Chem. 39(5), 746-756.

Yamamoto, M., Shimura, S., Itoh, Y., Ohsaka, T., Egawa, M., \& Inoue, S. (2000). Antiobesity effects of lipase inhibitor CT-II, an extract from edible herbs. Nomame Herba, on rats fed a highfat diet. Intl. J. Obesity., 24, 758-764. doi:10.1038/sj/ijo.0801222. 